\title{
Activities of Antioxidant and Detoxifying Enzymes in Rats after Lead Exposure
}

\author{
M. A. ALGHAZAL ${ }^{1}$, V. LENÁRTOVÁ ${ }^{2}$, K. HOLOVSKÁ ${ }^{2}$, A. SOBEKOVÁ ${ }^{2}$, \\ M. FALIS ${ }^{1}$, J. LEGÁTH ${ }^{1}$ \\ ${ }^{1}$ Department of Pharmacy, Pharmacology and Toxicology, ${ }^{2}$ Department of Chemistry, \\ Biochemistry and Biophysics, University of Veterinary Medicine, Košice, Slovak Republic \\ Received April 17, 2007 \\ Accepted June 11, 2008
}

\begin{abstract}
Alghazal M. A., V. Lenártová, K. Holovská, A. Sobeková, M. Falis, J. Legáth: Activities of Antioxidant and Detoxifying Enzymes in Rats after Lead Exposure. Acta Vet. Brno 2008, 77: 347-354.

The studies were undertaken to investigate the activity response of the antioxidant enzyme superoxide dismutase (SOD) and detoxifying enzyme glutathione-S-transferase (GST) of rats exposed to lead. Enzyme activities were determined in the liver, kidneys and heart of male and female rats that received $100 \mathrm{mg}$ and $1000 \mathrm{mg}$ of lead acetate per litre, respectively, in their drinking water for 18 weeks. Statistical analyses indicated differences related to the organs and to the sex of animals. Administration of lead evoked an increase of the SOD activity in the liver and kidneys both in male and female rats but only in the heart of female rats. GST activity decreased in the liver and heart of male rats, while this activity increased in the liver and heart of female rats. In kidneys, the lower lead dose resulted in a decrease of the GST activity in both groups but the higher dose evoked an increase of activity only in male rats. Thiobarbituric acid reactive substances (TBARS), an indicator of oxidative stress, significantly increased in rats that were given the high lead dose, in the kidneys of male rats and in the heart of female rats. Most probably, the observed changes could be a compensatory response to different lead accumulation in the male and female organs and also the possible distinct mechanisms in ROS elimination.
\end{abstract}

Lead intoxication, superoxide dismutase, glutathione-S-transferase, liver, kidneys, heart

Lead is a non-essential toxic heavy metal widely distributed in the environment and a chronic exposure to low levels of lead induces a broad range of physiological, biochemical and behavioural dysfunctions (Koller 1990; Feldman and White 1992; Yokoyama et al. 1997). Its toxicity is not well understood and various mechanisms have been suggested to explain it. These suggestions include disturbances in the mineral metabolism, demyelization of nerve tissues and inactivation of several enzymes (Vallee and Ulmer 1972; Ercal et al. 2001). Moreover, recent studies have proposed that one possible mechanism of lead toxicity is the disturbance of prooxidant and antioxidant balance by generation of reactive oxygen species (ROS) (Gurer and Ercal 2000; Wang et al. 2001). This can evoke the oxidative damage of critical biomolecules such as lipids, proteins and DNA. It has been also reported that lead exposure has a dose response relationship with changes in antioxidant enzyme levels and their activities (Adonaylo and Oteiza 1999). These enzymes include superoxide dismutase (SOD), catalase (CAT), glutathione peroxidase (GPx), expressions of which were found to be changed in animals and in workers exposed to lead (McGowan and Donaldson 1986; Bechara et al. 1993; Sugawara et al. 1991).

SOD has particular value as an antioxidant that can help to protect against cell destruction. The substrate of superoxide dismutases (SODs) is the superoxide radical anion $\left(\mathrm{O}_{2}^{-}\right)$which is generated by the transfer of one electron to molecular oxygen. It is responsible both for the direct damage of biological macromolecules and for generating other reactive oxygen species. SODs keep the concentration of superoxide radicals at low levels and therefore play an important role in the defence against oxidative stress (Fridovich 1997).

Address for correspondence:

Prof. Ing. Viera Lenártová, PhD.

Department of Chemistry, Biology and Biochemistry

University of Veterinary Medicine

Komenského 73, 04181 Košice

Phone: +421915992256

Slovak Republic

http://www.vfu.cz/acta-vet/actavet.htm 
Glutathione-S-transferases (GSTs) are also known to provide protection against oxidative stress. Some papers describe the changes in GSTs activity after the lead exposure (PlanasBohne and Elizalde 1992; Daggett et al. 1997). The GSTs are a family of cytosolic enzymes involved in the detoxification of a range of xenobiotic compounds by conjugation to glutathione which is essential in the maintenance of normal physiological processes (Hayes and Pulford 1995). Based on the above considerations this study was carried out to evaluate the changes in SOD and GST enzymatic activities in the liver, kidney and heart of rats exposed in the long term to lead compounds.

\section{Materials and Methods}

All reagents (the highest purity) were from Sigma, Merck and Boehringer.

Animals

Sixty-four clinically healthy male and female Wistar rats SPF, 24 weeks old, purchased from LF UPJŠ Košice were allowed to acclimate at the animal facility for a week before use. Only the animals found to be in a clinically acceptable condition were assigned to the study. They were housed by four in plexit cages for 18 weeks (temperature $22-24{ }^{\circ} \mathrm{C}$, humidity 60-70\%, $12 \mathrm{~h}$ day and night cycle). Males weighing $412 \pm 47 \mathrm{~g}$ and females weighing $290 \pm 19 \mathrm{~g}$ at the beginning of the experiment were housed separately. Pb 100 experimental groups (12 males and 12 females) were receiving $100 \mathrm{mg}$ of lead acetate per litre and $\mathrm{Pb} 1000$ experimental groups (12 males and 12 females) were receiving $1000 \mathrm{mg}$ of lead acetate per litre of drinking water for 18 weeks, respectively. The control groups (8 males and 8 females) were receiving only drinking water. All rats received the same standard diet ad libitum. On the last day of experiment, the animals were sacrificed by decapitation. The experiments were authorized by ŠVPS SR no. 7879/04-220/3.

Preparation of tissue extracts

Pieces of organs (liver, kidney, heart) were washed two times with cooled saline, cut into pieces and homogenized in $5 \mathrm{mmol} \cdot \mathrm{dm}^{-3}$ Tris-HCl buffer $\mathrm{pH} 7.8 \mathrm{containing} 0.15 \mathrm{~mol} \cdot \mathrm{dm}^{-3} \mathrm{KCl}, 1 \mathrm{mmol} \cdot \mathrm{dm}^{-3} \mathrm{Na}_{2}$ EDTA and $2 \mathrm{mmol} \cdot \mathrm{dm}^{-3} \mathrm{GSH}$ using Ultra-Turrax homogenizer. Homogenates $(25 \% \mathrm{w} / \mathrm{v})$ were centrifuged at $105000 \times \mathrm{g}$ for 60 min and supernatants were stored at $-50^{\circ} \mathrm{C}$ until used for enzyme assays.

Total superoxide dismutase activity (SOD, EC 1.15.1.1) was determined by measuring the inhibition of the cytochrome $\mathrm{C}$ reduction using xantine/xantine oxidase $\mathrm{O}_{2}^{-}$generating system at $550 \mathrm{~nm}$ (Flohé and Ötting 1984). One unit of SOD activity was defined as that amount of enzyme causing $50 \%$ inhibition of cytochrome $\mathrm{C}$ reduction under the assay conditions.

Glutathione-S-transferases activity (GSTs, EC 2.5.1.18) was measured by the procedure of Habig and Jacoby (1981) at $30^{\circ} \mathrm{C}$ using the substrate $\mathrm{CDNB}$ at a final concentration of $1 \mathrm{mmol} \cdot \mathrm{dm}^{-3}$.

Protein concentration was measured by the method of Bradford (1976), using bovine serum albumin as a standard.

Specific enzyme activity was expressed in $\mathrm{U} \cdot \mathrm{mg}^{-1}$ of protein.

Tissue content of thiobarbituric acid reactive substances (TBARS) was determined as described by Gutteridge (1984). TBARS content was expressed as absorbance at $535 \mathrm{~nm}$ per mg of protein.

Lead contents were determined by the atomic absorption spectroscopy method using Perkin Elmer A Analyst 100 (Krupicer 1995).

Statistics

The results are given as means $\pm \mathrm{SD}$. Data were analyzed using Student's $t$-test with the significance level of $p$ $<0.05, p<0.01$ and $p<0.001$, respectively.

\section{Results}

The contents of lead were determined in the liver, kidney and heart of rats after 18 weeks administration of $100 \mathrm{mg} / \mathrm{l}$ or $1000 \mathrm{mg} / \mathrm{l}$ of lead acetate, respectively. In the controls of female rats the contents of lead $(\mathrm{mg} / \mathrm{kg})$ were $0.050 \pm 0.009$ in the kidney, $0.025 \pm$ 0.004 in the liver and $0.017 \pm 0.001$ in the heart, respectively. In the controls of male rats the lead contents $(\mathrm{mg} / \mathrm{kg})$ were $0.06 \pm 0.02$ in the kidney, $0.033 \pm 0.006$ in the liver and $0.020 \pm 0.004$ in the heart, respectively. The lead contents in the organs of control and experimental animals are presented as a percent of control in Table 1 . The high increase of lead content was observed in the kidneys of male (70-fold) and female (230-fold) rats in $\mathrm{Pb} 1000$ groups. Activities of the antioxidant enzyme SOD and detoxifying enzyme GST were determined in the rats' parenchymal organs liver and kidneys, and in the muscle 
Table 1. Lead content in the organs

\begin{tabular}{|l|c|c|c|c|}
\hline \multirow{3}{*}{ Organs } & \multicolumn{4}{|c|}{ Lead content as percent of control (\%) } \\
\cline { 2 - 5 } & \multicolumn{3}{|c|}{ Male } & \multicolumn{2}{c|}{ Female } \\
\cline { 2 - 5 } & $\mathrm{Pb} \mathrm{100}$ & $\mathrm{Pb} 1000$ & $\mathrm{~Pb} \mathrm{100}$ & $\mathrm{Pb} 1000$ \\
\hline Liver & $250 \pm 10$ & $3190 \pm 13$ & $359 \pm 19$ & $9280 \pm 20$ \\
\hline Kidneys & $492 \pm 15$ & $7000 \pm 22$ & $410 \pm 22$ & $23000 \pm 29$ \\
\hline Heart & $205 \pm 14$ & $379 \pm 26$ & $246 \pm 12$ & $775 \pm 11$ \\
\hline
\end{tabular}

The data are means \pm SD
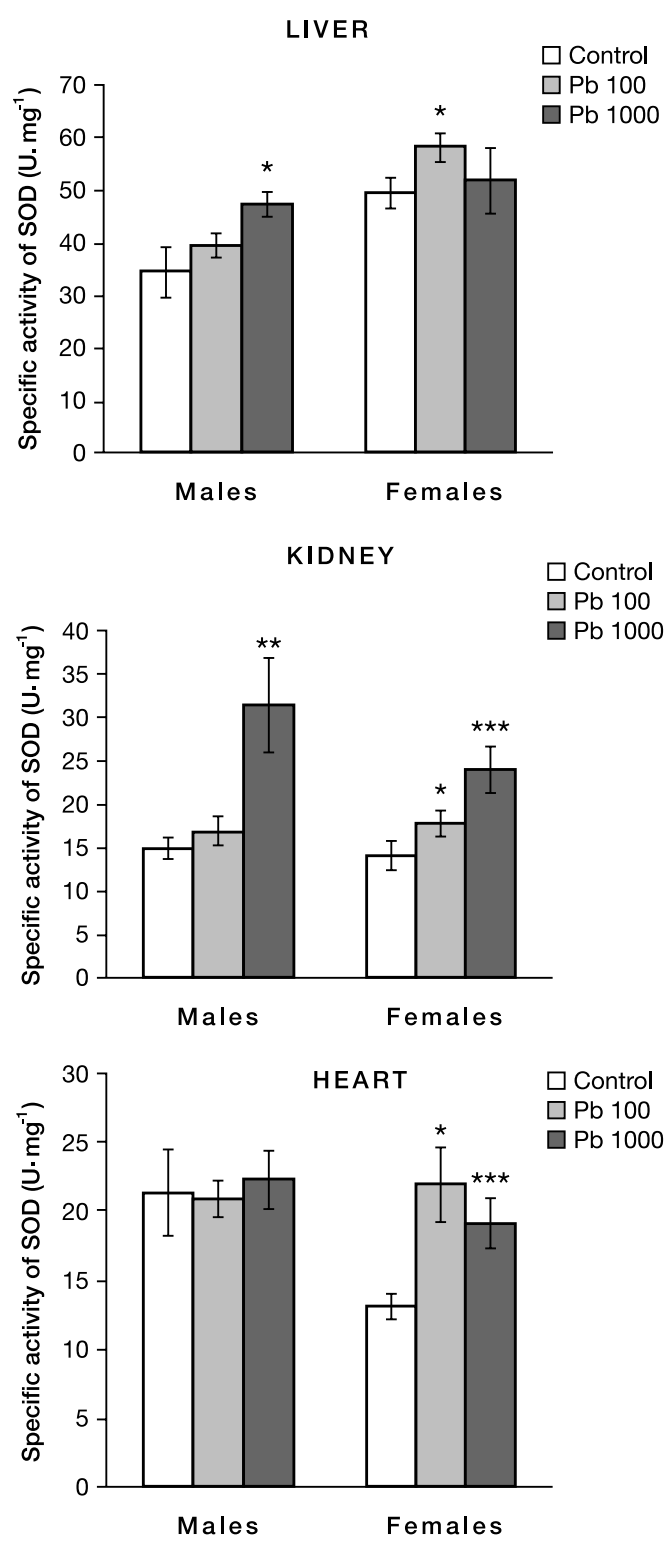

organ heart in the control group and in the experimental groups $\mathrm{Pb} 100$ and $\mathrm{Pb}$ 1000 , respectively. Statistical analyses indicated a significant effect of sex in the enzyme activities of organs. A significant increase of the SOD activity was observed in the liver, group $\mathrm{Pb} 1000$ of male rats, while in female rats the increase was seen in the Pb100 group. As for kidneys, the highest increase of the SOD activity occurred both in $\mathrm{Pb}$ 1000 male and female groups. While no changes were observed in the SOD activity in the male heart, SOD activity increased both in $\mathrm{Pb} 100$ and $\mathrm{Pb} 1000$ groups in the female heart (Fig. 1).

Lead is known to diminish reduced glutathione, the substrate for GST. In the male organs liver and heart the GST activity significantly decreased in $\mathrm{Pb} 1000$ groups. In contrast, in female groups the GST activity increased in liver $\mathrm{Pb} 100$ group and both in $\mathrm{Pb}$ 100 and $\mathrm{Pb} 1000$ groups in the heart. Interesting findings were determined in the kidneys. While the lower lead dose resulted in a decrease of the GST activity in $\mathrm{Pb} 100$ male and female groups, the high lead dose (Pb 1000 group) evoked an increase of the GST activity only in male rats (Fig. 2).

TBARS values, an indicator of oxidative stress, significantly increased only in groups of the high lead dose in the male kidneys and female heart (Fig. 3). It is possible that higher antioxidant

Fig. 1. Specific activity of SOD in the liver, kidney and heart of the rats given lead acetate. Values are given as means $\pm \operatorname{SD}(n=6)$. Asterisks represent significant differences between the control group and groups given lead acetate $\left({ }^{*} P<0.05, * * P<0.01\right.$, *** $\left.P<0.001\right)$. 
and detoxifying enzyme activities were able to prevent the increased production of TBARS in the organs.

\section{Discussion}

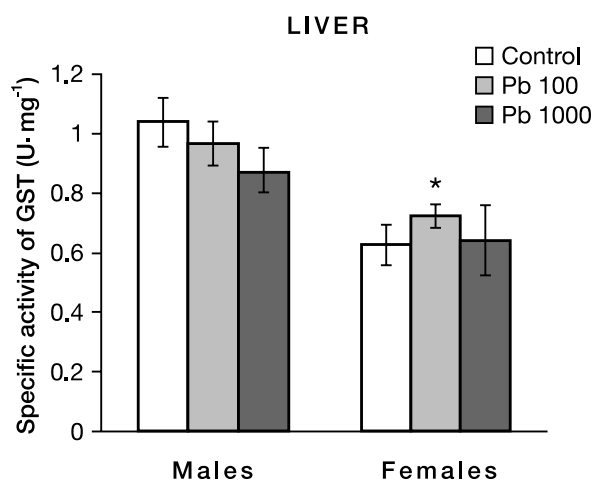

KIDNEY
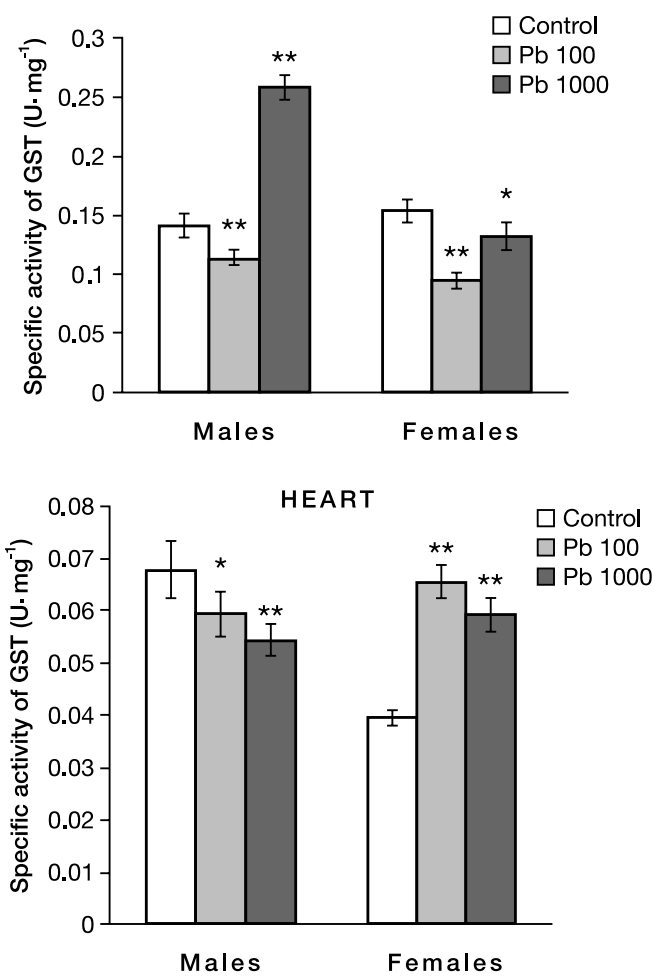

Fig. 2. Specific activity of GST in the liver, kidney and heart of the rats given lead acetate. Values are given as means $\pm \mathrm{SD}(\mathrm{n}=6)$. Asterisks represent significant differences between the control group and groups given lead acetate ( $\left.{ }^{*} P<0.05,{ }^{* *} P<0.01, * * * P<0.001\right)$.
Recent studies have reported lead as a potential agent for inducing oxidative stress by the production of ROS (Adonaylo and Oteiza 1999; Gurer and Ercal 2000; Wang et al. 2001). The concentration of ROS in the organism is controlled by several defence mechanisms, which involve also antioxidant and detoxifying enzymes. High activity of the antioxidant enzyme SOD is noticed in cells, especially in places where processes that need oxygen may be found - in the liver, kidneys and heart (Fridovich 1995).

Our previous experiments with rats given xenobiotics showed that the changes in antioxidant enzymes activities were influenced by the sex of animals (Holovská et al. 2005). So in the present work we followed the activities of the antioxidant enzyme SOD and detoxifying enzyme GST separately in the livers, kidneys and hearts of female and male rats exposed in the long term to lead. SOD activity was higher in the liver of female than that of male rats. Administration of lead evoked the increase of SOD activity. Lead is known to produce oxidative damage in the liver tissue by enhancing peroxidation of membrane lipids, a deleterious process solely carried out by free radicals (Kang et al. 2004). We did not find increased TBARS values, an indicator of oxidative damage in the liver of rats, so the lead did not evoke oxidative stress in this organ. More sensitive was the response of the kidney to lead exposure, especially in the male group. The higher dose of lead $(1000 \mathrm{mg} / \mathrm{l})$ evoked a significant increase in the SOD activity and also lipid peroxidation was confirmed by increased TBARS values. Exposure to lead is toxic to the haematopoietic and nervous systems, to bone, and to kidney (Nolan and Shaikh 1992). 
Furthermore, lead can induce pathological changes in the structure and function of this organ (Khalil-Manesh et al. 1992). The results of research on the lead influence on the SOD activity are divergent. In studies on animals with high exposure to this element, a decreased SOD activity in erythrocytes was often noted (Ito et al.1985; Mylroie et al. 1986). Adonaylo and Oteiza (1999) did not notice any changes in the SOD activity in the brain, whereas Sandhir et al. (1994) indicated a decrease in the activity of this enzyme. Decreased SOD activity observed by different authors (Sandhir and Gill 1995; Pillai and Gupta 2005; Moreira et al. 2001) may be caused by interaction between lead and copper, a metal necessary for the proper functioning of the SOD cytosol enzyme. Our results are compatible with the research of many authors who found increased SOD activity after lead exposure (Ye et al. 1999; Mousa et al. 2002; Vaziri et al. 2003; Kasperczyk et al. 2004; Farmand et al. 2005). Increased SOD activity in the female rat liver and in both female and male rat kidney in our experiment is probably a response to increased production of superoxide anion radicals caused by lead.

Most experimental studies have indicated that after the exposure of animals to lead there is an increased amount of oxidized glutathione with a parallel drop of reduced glutathione in different organs (Gurer et al.1999; Sivaprasad et al. 2003). Reduced glutathione is necessary for proper functioning of GST. In our experiment the activity of this enzyme significantly decreased in the kidney of both male and female rats in lower lead dose administration. On the other hand, the GST activity surprisingly increased in the liver and kidneys of male rats given the high dose of lead. Some studies have also demonstrated that a single injection of lead nitrate significantly increased renal GSTs, and acute administration of triethyl lead chloride induced GSTs in rat kidney but decreased hepatic GST levels (Planas-Bohne and Elizalde 1992; Dagget et al. 1997). In addition, chronic
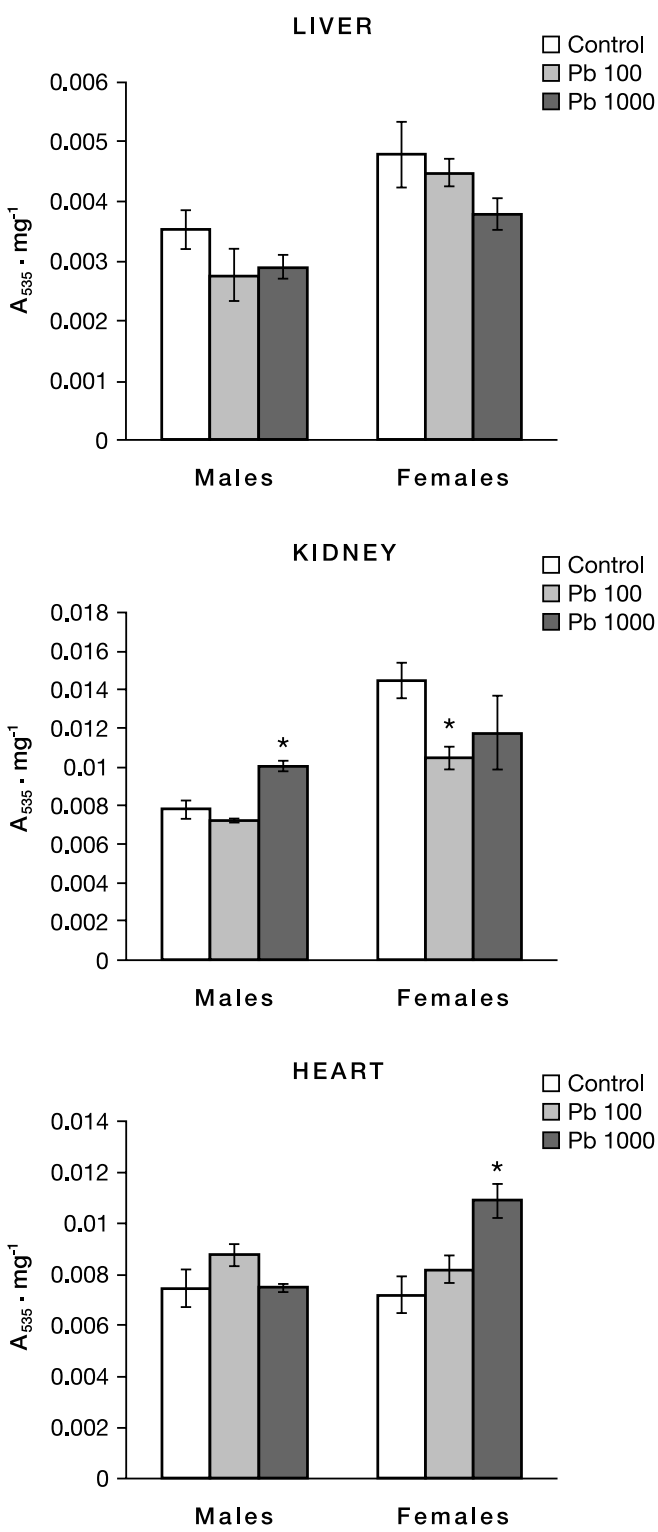

Fig. 3. TBARS content in the liver, kidney and heart of the rats given lead acetate. Values are given as means \pm SD (n $=6$ ). Asterisks represent significant differences between the control group and groups given lead acetate $(* P<0.05$, $* * P<0.01, * * * P<0.001)$. 
development or acute exposure produced cell-type specific increases in particular isoforms GST in the rat kidney (Oberley et al. 1995). Whether these changes in GSTs are a result of lead-generated injury or serve as a protective adaptation remains unclear.

The influence of lead administration on the antioxidant enzyme activities in the muscle tissue of heart was different than that in the parenchymal tissues of kidney and liver. Presented results also showed differences in the enzymatic answer to the lead intake between male and female groups. While the enzyme activities did not increase in the male group, in the female group even the lower dose of lead $(100 \mathrm{mg} / \mathrm{l})$ evoked increased SOD and GST activities. The higher TBARS content, an evidence of heart lipid peroxidation was seen only at higher lead dose administration. It has been reported that lead exposure has a dose response relationship with antioxidant enzyme changes (Adonaylo and Oteiza 1999). Some authors found that the heart is more susceptible to oxidative stress than other organs (Di Meo et al. 1996; Odom et al. 1992; Bordoni et al. 2003). Our previous experiments with selenium supplementation also showed a higher increase in the activities of antioxidant enzymes in heart than in other organs (Sobeková et al. 2006). Bermano et al. (1996) found different and tissue-specific regulation of mRNA and subsequent protein synthesis between organs. Results of long-term lead exposure in our experiments showed that there are differences in the antioxidant enzyme answers not only between organs but also between male and female rats. If gender differences are seen in toxic responses to xenobiotics, differences in biotransformation are the probable cause. Because male rats metabolize most foreign compounds faster than females, one would expect the biological half-life of most xenobiotics to be longer in the female than the male rat (Rispin et al. 2001). The differences in the antioxidant enzyme answers after lead exposure could be most probably a compensatory response to different lead accumulation in male and female organs and also possible distinct mechanisms in ROS elimination.

\section{Vplyv olova na aktivity antioxidačných a detoxikačných enzýmov u krýs}

Boli sledované zmeny aktivít antioxidačných enzýmov superoxiddismutázy (SOD) a detoxikačného enzýmu glutatión-S-transferázy (GST) u krýs po podávaní olova. Enzýmové aktivity boli stanovené v pečeni, obličkách a v srdci samcov a samíc krýs, ktoré dostávali 18 týždňov každý deň v pitnej vode 100 mg, resp. 1000 mg octanu olovnatého na liter. Analýzy ukázali štatistické rozdiely medzi orgánmi aj pohlaviami. Podávanie olova vyvolalo zvýšenie SOD aktivity v pečeni aj v obličkách u oboch pohlaví ale v srdci bola SOD aktivita zvýšená len u samíc. Aktivita GST sa znížila v pečeni a v srdci samcov ale naopak sa zvýšila $v$ pečeni a v srdci samíc. V obličkách bolo pozorované zníženie GST aktivity u samcov aj samíc po podaní nižších dávok olova. Vyššie dávky olova vyvolali zvýšenie GST aktivity len u samcov. Hodnoty TBARS (tiobarbituric acid reactive substances), indikátora oxidačného stresu sa signifikantne zvýšili v obličkách samcov a v srdci samíc, ktoré dostávali vyššie dávky olova. Pozorované zmeny a rozdiely v aktivite enzýmov u samcov a samíc môžu byt' dôsledkom rozdielnej akumulácie olova $v$ samčích a samičích orgánoch ako aj možného rozdielu mechanizmu eliminácie ROS u pohlaví.

\section{Acknowledgement}

The study was supported by NRL and Grant Agency VEGA 2/6175/6.

\section{References}

ADONAYLO VN, OTEIZA PI 1999: Lead intoxication: Antioxidant defenses and oxidative damage in rat brain. Toxicology 135: 77-85

BECHARA EJ, MEDEIROS MH, MONTEIRO HP, HERMES-LIMA M, PEREIRA B, DEMASI M 1993: A free 
radical hypothesis of lead poisoning and inborn porphyrias associated with 5-aminolevulinic acid overload. Quim Nova 16: 385-392

BERMANO G, NICOL F, DYER JA, SUNDE RA, BECKETT GJ, ARTHUR JR, HESKETH JE 1996: Selenoprotein gene expression during selenium-repletion of selenium deficient rats. Biol Trace Elem Res 51: 211-223

BORDONI A, BIAGI PL, ANGELONI C, LEONCINI E, MUCCINELLI I, HRELIA S 2003: Selenium supplementation can protect cultured rat cardiomyocytes from hypoxia/reoxygenation damage. J Agric Food Chem 51: 1736-1740

BRADFORD MM 1976: A rapid and sensitive method for the quantification of microgram quantities of protein utilizing the principle of protein-dye binding. Anal Biochem 72: 248-254

COSTA CA, TRIVELATO GC, PINTO AM, BECHARA EJ 1997: Correlation between plasma 5-aminolevulinic acid concentrations and indicators of oxidative stress in lead-exposed workers. Clin Chem 43: 1196-1202

DAGGETT DA, NUWAYSIR EF, NELSON SA, WRIGHT LS, KORNGUTH SE, SIEGEL FL 1997: Effects of triethyl lead administration on the expression of glutathione-S-transferase isoenzymes and quinone reductase in rat kidney and liver. Toxicology 117: 61-71

DI MEO S, VENDITTI P, DE LEO T 1996: Tissue protection against oxidative stress. Experientia 52: 786-794

ERCAL N, GURER-ORHAN H, AYKIN-BURNS N 2001: Toxic metals and oxidative stress. Part I: mechanisms involved in metal-induced oxidative damage. Curr Top Med Chem 1: 529-539

FARMAND F, EHDAIE A, ROBERTS CK, SINDHU RK 2005: Lead-induced dysregulation of superoxide dismutases, catalase, glutathione peroxidase, and guanylate cyclase. Environ Res 98: 33-39

FELDMAN RG, WHITE RF 1992: Lead neurotoxicity and disorders of learning. J Child Neurol 7: 354-359

FLOHÉ L, ÖTTING F 1984: Superoxide dismutase assays. Methods Enzymol 105: 93-104

FRIDOVICH I 1995: Superoxide radical and superoxide dismutases. Annu Rev Biochem 64: 97-112

FRIDOVICH I 1997: Superoxide anion radical $\left(\mathrm{O}_{2}^{-}\right)$, superoxide dismutases, and related matters. J Biol Chem 272: $18515-18517$

GOYER RA 1971: Lead and the kidney. Curr Top Pathol 55: 147-176

GURER H, ERCAL N 2000: Can antioxidants be beneficial in the treatment of lead poisoning? Free Radic Biol Med 29: 927-945

GURER H, OZGUNES H, OZTEZCAN S, ERCAL N 1999: Antioxidant role of alpha-lipoic acid in lead toxicology. Free Radic Biol Med 27: 75-81

GUTTERIDGE JMC 1984: Ferrous ion-EDTA-stimulated phospholipid peroxidation. Biochem J 224: 697-701

HABIG WH, JAKOBY WB 1981: Assays for differentiation of glutathione-S-transferases. Methods Enzymol 77: 398-405

HAYES JD, PULFORD DJ 1995: The glutathione-S-transferase supergene family: regulation of GST and the contribution of the isoenzymes to cancer chemoprotection and drug resistance. Crit Rev Biochem Mol Biol 30: $445-600$

HOLOVSKÁ Jr K, SOBEKOVÁ A, HOLOVSKÁ K, LENÁRTOVÁ V, JAVORSKÝ P, LEGÁTH J, LEGÁTH L, MARETTA M 2005: Antioxidant and detoxifying enzymes in the liver of rats after subchronic inhalation of the mixture of cyclic hydrocarbons. Exp Toxicol Pathol 56: 377-383

ITO Y, NIIYA Y, KURITA H, SHIMA S, SARAI S 1985: Serum lipid peroxide level and blood superoxide dismutase activity in workers with occupational exposure to lead. Int Arch Occup Environ Health 56: 119-127

KANG JK, SUL D, KANG JK, NAM SY, KIM HJ, LEE E 2004: Effects of lead exposure on the expression of phospholipid hydroperoxidase glutathione peroxide mRNA in the rat brain. Toxicol Sci 82: 228-236

KASPERCZYK S, BIRKNER E, KASPERCZYK A, ZALEJSKA-FIOLKA J 2004: Activity of superoxide dismutase and catalase in people protractedly exposed to lead compounds. Ann Agric Environ Med 11: 291-296

KHALIL-MANESH F, GONICK HC, COHEN AH, ALINOVI R, BERGAMASCHI E, MUTTI A, ROSEN VJ 1992: Experimental model of lead nephropathy. I. Continuous high-dose lead administration. Kidney Int 41: 1192-1203

KOLLER LD 1990: The immunotoxic effects of lead in lead-exposed laboratory animals. Ann N Y Acad Sci 587: $160-167$

KRUPICER J 1995: Effect of mercury-dominated heavy metal emission on the course of pasture helminthoses in sheep. Vet Med-Czech 40: 11-15

MCGOWAN C, DONALDSON WE 1986: Changes in organ nonprotein sulfhydryl and glutathione concentrations during acute and chronic administration of inorganic lead to chicks. Biol Trace Elem Res 10: 37-46

MONTEIRO HP, ABDALLA DS, ARCURI AS, BECHARA EJ 1985: Oxygen toxicity related to exposure to lead. Clin Chem 31: 1673-1676

MOREIRA EG, ROSA GJM, BARROS SB, VASSILIEFF VS, VASSILLIEFF I 2001: Antioxidant defense in rat brain regions after developmental lead exposure. Toxicology 169: 145-151

MOUSA HM, AL-QARAWI AA, ALI BH, ABDEL RAHMAN HA, ELMOUGY SA 2002: Effect of lead exposure on the erythrocytic antioxidant levels in goats. J Vet Med A-Physiol Pathol Clin Med 49: 531-534

MYLROIE AA, COLLINS H, UMBLES C, KYLE J 1986: Erythrocyte superoxide dismutase activity and other 
parameters of copper status in rats ingesting lead acetate. Toxicol Appl Pharmacol 82: 512-520

NOLAN CV, SHAIKH ZA 1992: Lead nephrotoxicity and associated disorders: Biochemical mechanisms. Toxicology 73: 127-146

OBERLEY TD, FRIEDMAN AL, MOSER R, SIEGEL FL 1995: Effects of lead administration on developing rat kidney. II. Functional, morphologic and immunohistochemical studies. Toxicol Appl Pharmacol 131: 94-107

ODOM AL, HATWIG CA, STANLEY, JS, BENSON AM 1992: Biochemical determinants of Adriamycin toxicity in mouse liver, heart and intestine. Biochem Pharmacol 43: 831-836

PILLAI A, GUPTA S 2005: Antioxidant enzyme activity and lipid peroxidation in liver of female rats co-exposed to lead and cadmium: effects of vitamin $\mathrm{E}$ and $\mathrm{Mn}^{2+}$. Free Radic Res 39: 707-712

PLANAS-BOHNE F, ELIZALDE M 1992: Activity of glutathione S-transferase in rat liver and kidneys after administration of lead or cadmium. Arch Toxicol 66: 365-367

RISPIN A, PODALL H, MEYER W 2001: Gender sensitivity of xenobiotics. In: The revised up-and-down procedure: a test method for determining the acute oral toxicity of chemicals NIH publication U.S. Public Health Service, pp. 663-682

SANDHIR R, GILL KD 1995: Effect of lead on lipid peroxidation in liver of rats. Biol Trace Elem Res 48 : 91-97

SANDHIR R, JULKA D, GILL KD 1994: Lipoperoxidative damage on lead exposure in rat brain and its implications on membrane bound enzymes. Pharmacol Toxicol 74: 66-71

SIVAPRASAD R, NAGARAJ M, VARALAKSHMI P 2003: Combined efficacies of lipoic acid and meso-2,3dimercaptosuccinic acid on lead-induced erythrocyte membrane lipid peroxidation and antioxidant status in rats. Hum Exp Toxicol 22: 183-192

SOBEKOVÁ A, HOLOVSKÁ K, LENÁRTOVÁ V, HOLOVSKÁ Jr K, JAVORSKÝ P, BOLDIŽÁROVÁ K, GREŠÁKOVÁ L, LENG L 2006: Effects of feed supplemented with selenite or Se-yeast on the antioxidant enzymes activities in the lamb tissues. J Anim Feed Sci 15: 569-577

SUGAWARA E, NAKAMURA K, MIYAKE T, FUKUMURA A, SEKI Y 1991: Lipid peroxidation and concentration of glutathione in erythrocytes from workers exposed to lead. Br J Ind Med 48: 239-242

VALLEE BL, ULMER DD 1972: Biochemical effects of mercury, cadmium and lead. Annu Rev Biochem 41: 91-128

VAZIRI ND, LIN CY, FARMAND F, SINDHU RK 2003: Superoxide dismutase, catalase, glutathione peroxidase and NADPH oxidase in lead-induced hypertension. Kidney Int 63: 186-194

WANG HP, QIAN SY, SCHAFER FQ, DOMANN FE, OBERLEY LW, BUETTNER GR 2001: Phospholipid hydroperoxide glutathione peroxidase protects against singlet oxygen-induced cell damage of photodynamic therapy. Free Radic Biol Med 30: 825-835

YOKOYAMA K, ARAKI S, MURAKA M, MORITA Y, KATSUNO N, TANIGAWA T, MORI N, YOKOTA J, ITO A, SAKATA E 1997: Subclinical vestibulo-cerebellar, anterior cerebellar lobe and spinocerebellar effects in lead workers in relation to current and past exposure. Neurotoxicology 18: 371-380

YE XB, FU H, ZHU JL, NI WM, LU YW, KUANG XY, YANG SL, SHU BX 1999: A study on oxidative stress in lead-exposed workers. J Toxicol Environ Health A 57: 161-172 